\title{
PHYSIOLOGICAL RESPONSE OF BROILER CHICKENS UNDER HEAT STRESS CONDITIONS FOR SOME ORGANIC ANTIOXIDANT ADDITIVES.
}

\author{
A. Gouda ${ }^{1}$; M.M.A. El-Moniary ${ }^{1}$; E.F. Eldaly ${ }^{1}$; I. El-Wardany ${ }^{2}$ and A.A. Hemid ${ }^{2}$ \\ ${ }^{1}$ Animal production Dept., Agric. \& Biologic. Research Division, National Research Center, Dokki, Cairo, \\ Egypt. \\ ${ }^{2}$ Poultry. Production Dept., Fac. of Agric. Ain Shams Univ., Shoubra El-Kheima, Cairo, Egypt.
}

SUMMARY

$\mathrm{O}$ ne hundred and twenty 1-d old commercial broiler chicks (Cobb) were divided in to four groups with six replicats, to investigate the effect of dietary supplementation with organic chromium $(\mathrm{Cr})$, organic selenium (Se) and Vitamin $\mathrm{E}$ (Vit.E) on some physiological and immunological parameters. The first group was the control group, while the second group was fed the basal diet supplemented with organic chromium $(0.8 \mathrm{mg} / \mathrm{kg}$ diet $)$, the third group was fed the basal diet supplemented with organic selenium $(0.3 \mathrm{mg} / \mathrm{kg}$ diet $)$ and the fourth group was fed the basal diet supplemented with vitamin E (200 IU/kg diet). Temperature and humidity were recorded daily and the Temperature-Humidity Index (THI) was calculated, which demonstrated that birds were exposed to heat stress throughout the experiment period. The results showed that increasing dietary levels of organic chromium, organic selenium and Vitamin $\mathrm{E}$ especially Vitamin E supplementation could improve plasma total protein and globulin $(\mathrm{p}<0.05)$ values at 42 DOA. Supplements could significantly $(\mathrm{p}<0.05)$ enhance the total antibody titer against Newcastle disease Virus (NDV) either for the primary or secondary response and induce higher expression of heat shock protein 70 (HSP 70). Insulin-like Growth factor-I (IGF-I) level was improved significantly $(\mathrm{p}<0.05)$ due to increasing dietary organic chromium levels followed by vitamin $\mathrm{E}$ than organic selenium. It could be concluded that the dietary addition of organic chromium $(\mathrm{Cr}$ ), organic selenium (Se) and Vitamin E (Vit.E) triggered improvements in the physiological and immunological measurements of broilers reared under heat stress conditions

Key words: Broiler, Vitamin E; selenium, Chromium, IGF-I and Hsp70

\section{INTRODUCTION}

Poultry production in tropical countries is affected by many challenges especially during the hot humid summer season. Economic losses result from decreased productivity and increased mortality due to acute heat stress. Acute heat stress at marketing age especially in broiler chickens raised in open houses with reduced means of heat exchange leads to economic losses. Homeostasis is constantly challenged by intrinsic and extrinsic stressors (Lin et al., 2006). Heat stress is of major concern for poultry industry, especially in the hot regions. The important traits governing productivity (growth performance, immune suppression and high mortality rate ..... etc) are adversely affected by heat stress (Mujahid et al., 2006, 2007 and Niu et al., 2009). Biochemical and physiological events associated with hyperthermia can potentially promote reactive oxygen species formation which results in the disturbance of balance between the oxidation and antioxidants defense systems, causing lipid peroxidation (LPO), in cell membranes, free radical peroxidation and oxidative injury in biological molecules, DNA and proteins (Lin et al., 2006; Mujahid et al., 2006 and 2008 and Aslam et al., 2010). Furthermore, heat stress increases mineral and vitamin mobilization from tissues and their excretion, thus may exacerbate a marginal vitamin and mineral deficiency or an increased mineral and vitamin requirement, several methods are available to alleviate the negative effects of heat stress, mostly focused on dietary manipulation.

It could be concluded that under environmental stressful conditions, as the bird's body attempts to maintain its thermal homeostasis, increased levels of reactive oxygen species (ROS) occur. As a consequence, the body enters a stage of oxidative stress, and starts producing and releasing heat shock proteins (HSP) to try and protect itself from the deleterious cellular effects of ROS (Droge 2002). Also many HSP are expressed as an emergency response to diverse stressor agents, and that increased synthesis of these proteins seems to be involved in protection of stressed cells and organisms (Gabriel et al., 2003). 


\section{Gouda et al.}

Stress thus may exacerbate a marginal chromium $(\mathrm{Cr})$ deficiency or an increased $\mathrm{Cr}$ requirement, $\mathrm{Cr}$ is used in the poultry diet because of the reported benefits of $\mathrm{Cr}$ supplementation in broiler under heat stress because of the fact that stress condition increase chromium mobilization from the tissues that is irreversibly excreted (Sahin et al., 2002a and 2003). Cr plays a regulatory role in insulin action and consequently, in nutrient metabolism (Sands and Smith, 2002). It is also an integral part of bimolecular such as glucose tolerance factor and chromodulin, a cofactor of certain enzymes and necessary for stabilization of proteins and nucleic acids. Bahrami et al. (2012) reported that antibody titers against Newcastle virus were higher $(\mathrm{p}<0.05)$ in broilers received organic $\mathrm{Cr}$ supplements at 18 and 30d of age. Samar et al. (2014), recorded that supplementation of $\mathrm{Cr}$ to broiler diets were significantly affected on serum total protein by increasing its level under heat stressed compared to the control group

Dietary Se plays an important role in all aspects of the immune system (Arthur et al., 2003). El-Sheikh et al. (2010) stated that, selenium supplementation especially at 0.2 and $0.3 \mathrm{mg} / \mathrm{kg}$ diet significantly $(\mathrm{P} \leq 0.05)$ increased serum total protein and globulin 0.2 and 0.3 selenium compared with the control group, while, no significant effects on serum albumin concentrations was observed. Chicks fed diet supplemented with sodium selenite solution at a dose of $0.23,0.50,0.75$ and $1.5 \mathrm{mg} / \mathrm{kg}$ resulted in an increase of antibody titers against Newcastle disease (Yang et al. 2000). Mahmoud and Edens (2003 and 2005) have clearly shown that chickens provided with organic selenium in yeast are more resistant to thermal stress than chickens fed inorganic sodium selenite, and this was demonstrated by a lower expression of HSP70.

Vitamin E (Vit.E) were discovered and its role as an antioxidants was further characterized (Wolf, 2005). The Vit.E that is integrated into cellular membranes exerts its antioxidant effects by intercepting peroxyl radicals more rapidly than can polyunsaturated fatty acids (Burton and Traber, 1990). In one-day-old unsexed Hubbard broiler chicks Metwally, (2003) found that vitamin E levels significantly $(\mathrm{P}<0.05)$ affected plasma albumin when supplementing the diet with either vitamin E (10, as recommended by NRC and high level as $150 \mathrm{IU} / \mathrm{kg}$ ) from hatch till 6 week of age. Weberi et al. (2008) reported that haemagglutination titers against NDV increased in comparison to the controls as an effect of vitamin E supply in drinking water (10.5 mg/animal-day-1) for 14 days . Kapakin et al. (2013) when they studied Effect of Vit E on HSP 70, they found that, the highest secretion level of HSP-70 was in the control negative group (24o C), while the lowest secretion level of HSP-70 was in the control positive group (34o C), when vitamin E is administered the secretion of HSP-70 increases in control positive group (34o C) plus (DL $\alpha$ Tocopheryl acetate: 150 $\mathrm{mg} / \mathrm{kg}$ ) in addition to basal ration.

Therefore, the objective of the present study is to elucidate the effect of increasing dietary supplements levels of organic chromium, organic selenium and Vitamin E on some physiological changes in blood components, antibody titer against Newcastle Disease Virus (NDV), Insulin-like Growth factor -I (IGF-I) and heat shock protein 70 (Hsp70) of broilers under heat stress conditions. Finally, results from this study could provide a fundamental knowledge for using antioxidants to reduce oxidative stress and improve some physiological and immunological parameters in broiler production under hot climates of summer season in Egypt.

\section{MATERIALS AND METHODS}

\section{Experimental procedures:}

A total of 120 1-d old commercial broiler chicks (Cobb) were obtained from a local hatchery. Upon arrival, the chicks were divided into four groups with six replications, each of five chicks. The first group was the control group, while the second group was fed the basal diet supplemented with $0.8 \mathrm{mg} / \mathrm{kg} \mathrm{diet}$ organic Chromium, the third group was fed basal diet supplemented with $0.3 \mathrm{mg} / \mathrm{kg}$ diet organic selenium, the fourth group was fed basal diet supplemented with $200 \mathrm{IU} / \mathrm{kg}$ diet vitamin E. At 42-d of age all groups were exposed to $41 \pm 1^{\circ} \mathrm{C}$ for $1 \mathrm{~h}$.

Maximum and minimum temperature $\left({ }^{\circ} \mathrm{F}\right)$ and relative humidity in breeding houses illustrated in Table (1). The Temperature-Humidity Index (THI) was calculated using the following formula (World Meteorological Organization (W.M.O), 1996), to determine the level of stress by using the Table (2) which explained THI ranges and their corresponding stress categories (Smith et al., 1998).

$$
\mathrm{THI}=\mathrm{T}_{\mathrm{d}}-[0.55-(0.55 * \mathrm{RH} / 100)] *\left(\mathrm{~T}_{\mathrm{d}}-58\right) .
$$


Where; THI = Temperature Humidity Index; $\quad$ Td = dry bulb temperature in degrees Fahrenheit; RH = relative humidity $(\%)$.

The experimental diets and their calculated analysis are shown in Table (3). Feed and water were offered ad libitum and artificial light was provided for 23 hours daily all over the experimental period, which lasted for 6 weeks. Chicks of the four treatments were kept under similar hygienic and environmental conditions and vaccinated against common diseases.

\section{Measurements:}

\section{Plasma total protein (PTP), albumin (A), globulin $(G)$ and albumin to globulin ratio (A/G ratio).}

Plasma total proteins ( $\mathrm{g} / \mathrm{dl}$ ) were determined according to the method described by Henry (1974). The determination of plasma albumin $(\mathrm{g} / \mathrm{dl})$ based on a colorimetric method was conducted as described by Doumas et al. (1971). Globulin was calculated by subtraction of plasma albumin from plasma total protein, and then $\mathrm{A} / \mathrm{G}$ ratio was calculated.

Table (1): In door maximum and minimumTemperature $\left({ }^{\circ} \mathbf{F}\right)$, relative humidity and Temperature Humidity index.

\begin{tabular}{cccccc}
\hline $\begin{array}{c}\text { Age } \\
(\text { Week })\end{array}$ & $\begin{array}{c}\text { Minimum } \\
\text { Temperature }\left({ }^{\circ} \mathrm{F}\right)\end{array}$ & $\begin{array}{c}\text { Maximum } \\
\text { Temperature }\left({ }^{\circ} \mathrm{F}\right)\end{array}$ & $\begin{array}{c}\text { Relative humidity } \\
(\%)\end{array}$ & $\begin{array}{c}\text { THI } \\
\text { min. }\end{array}$ & THI max. \\
\hline 1 & 87.8 & 94.75 & 68.86 & 82.7 & 88.5 \\
2 & 86.95 & 89.85 & 69.71 & 82.1 & 84.5 \\
3 & 83.57 & 94.48 & 74.43 & 79.9 & 89.3 \\
4 & 85.64 & 96.12 & 74.6 & 81.8 & 90.8 \\
5 & 86 & 97.70 & 75.4 & 82.2 & 92.3 \\
6 & 88.56 & 100.31 & 76.5 & 84.6 & 94.8 \\
\hline
\end{tabular}

Table (2): Temperature Humidity index ranges and their corresponding stress categories.

\begin{tabular}{lc}
\hline Stress Category & THI range (inclusive) \\
\hline No stress & $<72$ \\
Mild stress & $72-79$ \\
Heat stress & $80-89$ \\
Severe stress & $90-98$ \\
Death & $>99$ \\
\hline
\end{tabular}

\section{Antibody titer against Newcastle Disease Virus (NDV).}

Vaccination program: All chicks were vaccinated with the NDV vaccine: Hitchnar B1 strain vaccine at 7 DOA and repeated with LaSota strain vaccine at 21 day of age. The primary and secondary immunization, at 20 and 30; 40 DOA were used to evaluate the primary and secondary antibody titer (Hitchner et al., 1980). Each Plasma samples were collected ten days after the first and the second vaccination to determine the immune responses for total antibodies response against NDV, using microtitre U-shape plate of 96 wells.

\section{Insulin-Like Growth Factors (IGF-1)}

Insulin-Like Growth Factors (IGF-1) was determined with commercial kits (Gammacoat, kits, clinical assay, Cambridge, Medical Diagnostics, and Boston, MA) as reported by Houston and Neill (1991).

\section{Measurement of Heat shock proteins:}

Liver tissue samples were homogenized and completely washed in ice-cold physiological saline. The Hsp70 in the liver of both heat-stressed and control broilers were measured by enzyme-linked immunosorbent assay (ELISA). Enzyme linked immunosorbent assay for liver hsp70 was performed as described by Anderson et al., (1993).

\section{Statistical analysis:}

Data obtained were statistically analyzed using the General Liner Model of SAS (2009). Significant differences among means were tested by Duncan's Multiple Range Test Duncan (1955). 


\section{Gouda et al.}

Table (3). Composition and calculated analysis of the experimental diets.

\begin{tabular}{|c|c|c|c|}
\hline Ingredient & $\begin{array}{c}\text { Starter \% } \\
1-21 \mathrm{D}\end{array}$ & $\begin{array}{c}\text { Grower \% } \\
22-42 \mathrm{D}\end{array}$ & $\begin{array}{l}\text { *: Vitamin and mineral } \\
\text { mixture per kg of diet: }\end{array}$ \\
\hline Yellow corn & 55.35 & 60.45 & \multirow{19}{*}{ 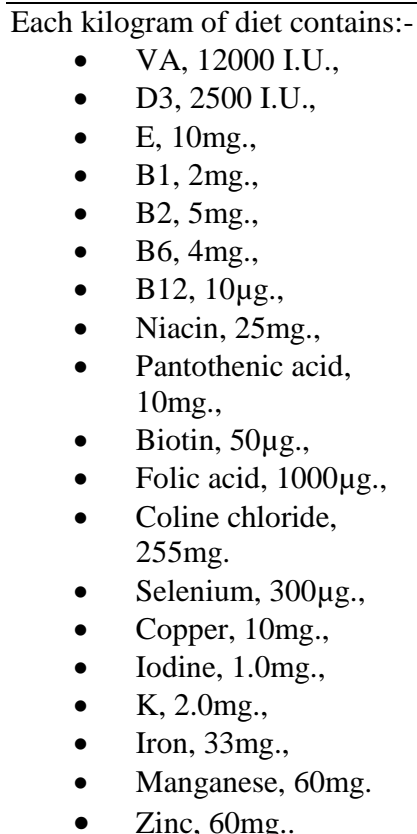 } \\
\hline Soybean meal (44\%) & 27.5 & 25 & \\
\hline Corn gluten meal (62\%) & 8.9 & 6 & \\
\hline Mono-Ca phosphate & 1.65 & 1.6 & \\
\hline Limestone & 1.7 & 1.65 & \\
\hline Vegetable oil & 3.7 & 4.15 & \\
\hline Salt & 0.45 & 0.4 & \\
\hline Methionine & 0.15 & 0.15 & \\
\hline Lysine & 0.3 & 0.3 & \\
\hline Vitamin and mineral mixture & 0.3 & 0.3 & \\
\hline Total & 100 & 100 & \\
\hline Calculated analysis & & & \\
\hline $\mathrm{ME} \mathrm{kcal} / \mathrm{kg}$ & 3143 & 3190 & \\
\hline Crude protein $\%$ & 22.77 & 20.31 & \\
\hline Lysine \% & 1.27 & 1.19 & \\
\hline Methionine \% & 0.55 & 0.51 & \\
\hline Methionine+ Cystine \% & 0.93 & 0.85 & \\
\hline Calcium \% & 1.00 & 0.97 & \\
\hline Av.Phosphorus \% & 0.47 & 0.47 & \\
\hline
\end{tabular}

\section{RESULTS AND DISCUSSION}

\section{Plasma total protein (PTP), albumin (A), globulin (G) and albumin to globulin ratio (A/G ratio).}

Results of plasma total protein fractions as influenced by dietary supplements of organic chromium, organic selenium and Vitamin E are presented in Table (4). At 21 and 42 DOA, the present data show significantly $(\mathrm{p}<0.05)$ higher values of plasma total protein and globulin for treated chicks compared with control ones, with insignificant difference between the $\mathrm{Cr}$ fed chicks and control. Albumin levels were lower for the control and $\mathrm{Cr}$ group compared with Se and Vit.E groups; however the differences were not significant. Albumin to globulin ratio (A/G ratio) was significantly lower in the treatment groups compared with the control group which may suggest an improvement in the immune responses of chicks from the treatments groups. These results are consistent with previous studies by Sahin et al. (2002b) and Rashidi et al. (2010); found that vitamin E supplementation increased plasma total protein, albumin and globulin concentration. Also Cetin et al. (2002) found that when broilers were fed diets supplemented with $0.3 \mathrm{ppm}$ organic Se total protein was significantly increased compared with the control. It appears that, Vit.E as an antioxidant and selenium reduces free- radical induced pathological changes during both normal metabolic states and inflammation. (Packer and Suzuki, 1993). As a primary antioxidant of cell membranes, Vit.E is particularly important for the prevention of fatty acid peroxidation (Benedich, 1990). Fatty acids can act as immunoregulatory molecules that mediate cellular communication, this prevents have made a good indicator for increasing plasma total protein, albumin and globulin concentration (Leshchinsky and Klasing 2001). The role of $\mathrm{Cr}$ supplementation to diet was also observed and it confirms the findings by Uyanik et al., (2002) and El-Hommosany, (2008) who obtained comparable results. They found that Cr increased serum protein, albumin and globulin and attributed the positive effects of $\mathrm{Cr}$ on plasma protein and its fractions to the anabolic action of insulin mediated through increasing the amino acids synthesis by liver and enhancement the incorporation of several amino acids into protein. 
Table (4). Effect of dietary supplementation with organic chromium, organic selenium and Vitamin $E$ on plasma total protein (PTP), albumin (A) globulin (G) and albumin to globulin ratio (A/G ratio).

\begin{tabular}{|c|c|c|c|c|c|c|}
\hline \multirow{2}{*}{ Age (days) } & \multirow[b]{2}{*}{ Trait } & \multicolumn{3}{|c|}{ Treatment } & \multirow[b]{2}{*}{ Vit. E } & \multirow[b]{2}{*}{ Significance } \\
\hline & & Control & Chromium & Selenium & & \\
\hline \multirow{8}{*}{ 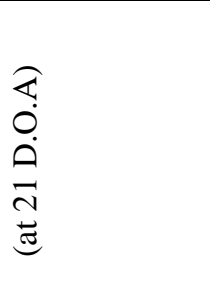 } & PTP & $4.01^{b}$ & $4.67^{\mathrm{ab}}$ & $5.07^{\mathrm{a}}$ & $5.19^{\mathrm{a}}$ & \\
\hline & $(\mathrm{g} / \mathrm{dl})$ & \pm 0.303 & \pm 0.705 & \pm 0.225 & \pm 0.494 & * \\
\hline & Albumin & 1.83 & 1.60 & 1.87 & 1.99 & \\
\hline & $(\mathrm{g} / \mathrm{dl})$ & \pm 0.304 & \pm 0.146 & \pm 0.265 & \pm 0.220 & NS \\
\hline & Globulin & $2.17^{\mathrm{a}}$ & $3.07^{\mathrm{b}}$ & $3.20^{\mathrm{b}}$ & $3.20^{\mathrm{b}}$ & \\
\hline & $(\mathrm{g} / \mathrm{dl})$ & \pm 0.272 & \pm 0.626 & \pm 0.232 & \pm 0.274 & $*$ \\
\hline & A/G ratio & $0.85^{\mathrm{a}}$ & $0.53^{\mathrm{b}}$ & $0.59^{\mathrm{b}}$ & $0.62^{b}$ & \\
\hline & & \pm 0.200 & \pm 0.093 & \pm 0.110 & \pm 0.017 & $*$ \\
\hline \multirow{8}{*}{ 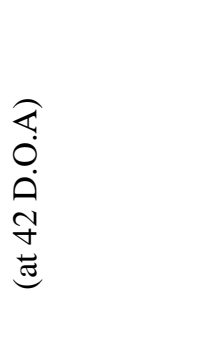 } & PTP & $4.58^{\mathrm{b}}$ & $6.36^{\mathrm{a}}$ & $6.88^{\mathrm{a}}$ & $6.54^{\mathrm{a}}$ & \\
\hline & $(\mathrm{g} / \mathrm{dl})$ & \pm 0.494 & \pm 0.793 & \pm 0.390 & \pm 0.538 & $*$ \\
\hline & Albumin & 2.80 & 3.03 & 3.10 & 2.77 & \\
\hline & $(\mathrm{g} / \mathrm{dl})$ & \pm 0.203 & \pm 0.298 & \pm 0.450 & \pm 0.257 & NS \\
\hline & Globulin & $1.78^{\mathrm{b}}$ & $3.33^{\mathrm{a}}$ & $3.77^{\mathrm{a}}$ & $3.76^{\mathrm{a}}$ & \\
\hline & $(\mathrm{g} / \mathrm{dl})$ & \pm 0.353 & \pm 0.495 & \pm 0.139 & \pm 0.572 & $*$ \\
\hline & $\mathrm{A} / \mathrm{G}$ ratio & $1.613^{\mathrm{a}}$ & $0.933^{\mathrm{b}}$ & $0.826^{\mathrm{b}}$ & $0.753^{\mathrm{b}}$ & \\
\hline & & \pm 0.286 & \pm 0.180 & \pm 0.141 & \pm 0.163 & * \\
\hline
\end{tabular}

$\overline{a, b, c}$ Means $\pm S D$ within a row with different superscripts are significantly different $(P \leq 0.05)$.

$N S=$ non-significant, $*=P \leq 0.05$.

\section{Antibody titer against Newcastle Disease Virus (NDV).}

Primary and secondary antibodies production against NDV in response to dietary supplementes are presented in Table (5). It is clear from the results that dietary supplements have significant $(\mathrm{p}<0.05)$ effects on antibody production against NDV either for the primary or secondary responses. The highest values were obtained for vitamin E, organic selenium and organic chromium compared with control groups, respectively. In this context supplemental Vit.E enhances the immune response (antibody response) of broilers (Packer and Suzuki, 1993). Also, Deng et al. (2001) reported that dietary Se up to $1.0 \mathrm{ppm}$ enhanced the immune function. Similarly, Swain et al. (2000) reported that feeding broiler chicks with vitamin E significantly increased antibody production against Newcastle disease virus. This result was explained by the previous findings that Se has an impact on the immune system through the up-regulation of the interleukin (IL)-2 receptor $\alpha$ and $\beta$ subunits on lymphocytes that causes a greater affinity for the cytokine IL-2, which enhances proliferation of B cells, T cells, and natural killer (NK) cells (Gowdy, 2004). Moreover, Cao et al. (2004) and Lee et al. (2003) reported that total antibody production tended to be higher $(\mathrm{P}<0.05)$ in $\mathrm{Cr}$ added groups, Immunoglobulin titers to NDV also tended to increase with adding $\mathrm{Cr}$ to the basal diet at secondary immune response, which is in close agreement with the present results.

Table (5). Effect of dietary supplementation with organic chromium, organic selenium and Vitamin $\mathbf{E}$ on Titration against Newcastle Disease Virus (NDV) of broiler chicks at 42 day of age.

\begin{tabular}{|c|c|c|c|c|c|c|}
\hline \multirow[b]{2}{*}{ Trait } & \multirow[b]{2}{*}{ Age } & \multicolumn{4}{|c|}{ Treatment } & \multirow[b]{2}{*}{ Significance } \\
\hline & & Control & Chromium & Selenium & Vit. E & \\
\hline \multirow{3}{*}{ Primary } & $20 \mathrm{~d}$ & $4.33^{\mathrm{c}}$ & $5.66^{b}$ & $7.00^{\mathrm{a}}$ & $7.33^{\mathrm{a}}$ & \\
\hline & & \pm 0.57 & \pm 0.57 & \pm 1.0 & \pm 0.57 & * \\
\hline & $30 \mathrm{~d}$ & $5.1^{\mathrm{c}}$ & $6.7^{b}$ & $8.1^{\mathrm{a}}$ & $8.2^{\mathrm{a}}$ & \\
\hline \multirow{3}{*}{ Secondary } & & \pm 0.57 & \pm 0.57 & \pm 1.0 & \pm 0.57 & * \\
\hline & $40 \mathrm{~d}$ & $3.2^{\mathrm{c}}$ & $4.61^{\mathrm{b}}$ & $6.01^{\mathrm{a}}$ & $6.23^{\mathrm{a}}$ & \\
\hline & & \pm 0.57 & \pm 0.57 & \pm 1.0 & \pm 0.57 & $*$ \\
\hline
\end{tabular}

$\overline{a, b, c}$ Means $\pm S D$ within a row with different superscripts are significantly different $(P \leq 0.05)$.

$N S=$ non-significant,$*=P \leq 0.05$.

\section{Insulin-like Growth factor -I (IGF-I)}

Table (6) presents the results of IGF-I level as affected by dietary supplements of organic chromium, organic selenium and Vitamin E. It appears that the higher level was obtained for chicks that fed organic 
chromium supplemented group followed by vitamin E and then organic selenium supplemented groups, however the lowest level was obtained from the control group. It is well known that increasing dietary $\mathrm{Cr}$ level has increased plasma insulin hormone concentration (Sahin et al., 2001 and 2002a; and ElHommosany, 2008), and this effect may be enhanced by dietary Vit.E and Se addition. Moreno, et al. (2001) indicated that Se is particularly important for IGF's bioactivity. Moreover, IGF-I level was significantly increased in chicks produced from young than old hens. This may be related to the relationships between the anabolic hormones, $\mathrm{T}_{3}, \mathrm{~T}_{4}, \mathrm{GH}$...etc. during the growing periods and the possible effect of vitamin $\mathrm{E}$ and organic selenium as antioxidant. Christensen et al. (2001) found that the control line of turkey had elevated IGF-I concentrations in response to higher temperatures.

Table (6). Effect of dietary supplementation with organic chromium, organic selenium and Vitamin E on Insulin-like Growth factor -I (IGF-I) at 42 DOA.

\begin{tabular}{cccccc}
\hline & \multicolumn{5}{c}{ Treatment } \\
\cline { 2 - 5 } Trait & Control & Chromium & Selenium & Vit. E & Significance \\
\hline & $39.16^{\mathrm{c}}$ & $46.46^{\mathrm{a}}$ & $40.46^{\mathrm{b}}$ & $41.36^{\mathrm{b}}$ & \\
IGF-I & \pm 0.35 & \pm 0.73 & \pm 0.70 & \pm 0.73 & $*$ \\
\hline
\end{tabular}

$\overline{a, b, c}$ Means $\pm S D$ within a row with different superscripts are significantly different $(P \leq 0.05)$.

$N S=$ non-significant, $*=P \leq 0.05$.

\section{Heat shock protein 70 (Hsp70).}

Results of the Hsp70 quantity in the liver tissues of heat exposed broilers at 21 and 42 DOA are shown in Table (7). The results at 21 DOA showed that dietary supplements have non-significant effect on Hsp70 at this age. However, there is an increase due mainly to dietary supplements. This was not observed at 42 DOA where all birds were exposed to $41^{\circ} \mathrm{C} \pm 1$ for one hour, which may increase Hsp70 production. This resulted in significant increases in Hsp70 for chicks of the treatment groups compared by control. The results of the present study showed similar trends for the effects of vitamin E on Hsp70, it was also suggested that vitamin E act synergistically (McDowell, 1989). In addition, the overall antioxidant potential was reported to possibly be more efficient and crucial than single antioxidant nutrients (Gallo- Torres, 1980). Selenium had the ability to reduce the impact of a heating episode. Mahmoud and Edens., (2003) have shown that heat distress induces oxidative stress, and oxidative stress is characterized by production of excessive reactive oxygen species (ROS), which are known to induce Hsp70. Furthermore, there are data that suggest a strong relationship among glutathione depletion, thiol-oxidation and Hsp70 synthesis in stressed cells that would affect the structure of proteins by allowing the unfolding of a fraction of these proteins leading to heat shock factor activation (Zou et al. 1998).

Table (7). Effect of dietary supplementation with organic chromium, organic selenium and Vitamin E on Heat shock protein 70 (Hsp70) of broiler chicks at 42 day of age.

\begin{tabular}{lccccc}
\hline \multirow{2}{*}{ Trait } & \multicolumn{4}{c}{ Treatment } & \\
\cline { 2 - 5 } & Control & Chromium & Selenium & Vit. E & Significance \\
\hline HSP70 ( ng/mg TP) & 3.93 & 4.54 & 4.61 & 4.71 & \\
(at 21 DOA) & \pm 0.64 & \pm 0.35 & \pm 0.51 & \pm 0.76 & NS \\
HSP70 ( ng/mg TP) & $4.66^{\mathrm{b}}$ & $5.91^{\mathrm{a}}$ & $6.01^{\mathrm{a}}$ & $6.04^{\mathrm{a}}$ & \\
(at 42 DOA) & \pm 0.35 & \pm 0.62 & \pm 0.30 & \pm 0.55 & $*$ \\
\hline
\end{tabular}

$\overline{a, b, c}$ Means $\pm S D$ within a row with different superscripts are significantly different $(P \leq 0.05)$.

$N S=$ non-significant, $*=P \leq 0.05$.

\section{REFERENCES}

Anderson, R.A., N.A. Bryden; M.M. Polansky (1993). Form of chromium affects tissue chromium concentration. FASEB J. 7A, 204-209.

Arthur, J.R.; R.C. McKenzie and G.J. Beckett (2003). Se in the immune system. J. Nutr.133:1457S-1459S.

Aslam, F.; Khan, M. Z.; Khan, S.; Sharaf, S. T.; Gulang, M. K. and Saleemi M. K. (2010): toxicopathological changes induced by cypermethrin in broiler chicks: their attenuation with Vitamin $\mathrm{E}$ and selenium. Experimental and Toxicologic, 62: 441-450. 
Bahrami, A., M.M. Moeini; S.H. Ghazi and M.R. Targhibi (2012). The effect of different levels of organic and inorganic chromium supplementation on immune function of broiler chicken under heat-stress conditions. J. of Applied Poult. Res. 21: 209-215.

Benedich, A. (1990). Antioxidant vitamins and their function in immune response. Pages 35-55 in:Advances in Experimental Medicine and Biology. Vol. 262. Plenum Press, New York, NY.

Burton, G. M. and M. G. Traber (1990). Vitamin E: Antioxidant activity, biokinetics, and bioavailability. Annu. Rev. Nutr. 10:357-382.

Cao, J.Y., K. Li, X.C. Lu and Y.X. Zhao, (2004). Effect of florfenical and chromium (III) on humoral immune response in chicks. Asian Austr. J. Anim. Sci., 17: 366-370.

Cetin, M.; G. Deniz; U. Polat and A. Yalcin. (2002). The effects of inorganic and organic selenium supplementation on biochemical blood parameters in broilers. Veteriner Fakultesi Dergisi Uludag Universites, 21: 1-3, 59-63.

Christensen, V.L.; J.P. McMurtry; W.E. Donaldson; and K.E. Nestor (2001). Incubation Temperature Affects Plasma Insulin-Like Growth Factors in Embryos from Selected Lines of Turkeys. Poult. Sci., 80:949-954.

Deng, H; H. Yang; Y. Liu and Y. He. (2001). Effects of immuno enhancement selenium on immune function in chickens. Chinese Vet. Sci., 21 : 96-98.

Doumas, B. T.; W.A. Warson and N.G. Biggs (1971). Albumin standards and the measurement of serum albumin with bromcresol green. Clin. Chem. Acta., 31:87-96.

Droge, W. (2002). Free radicals in the physiological control of cell function. Physiol. Rev., 82, 47-95.

Duncan, D. B. (1955). Multiple range and multiple F tests. Biometrics 11:1- 42.

El-Hommosany Y.M., (2008). Study of the Physiological Changes in Blood Chemistry, Humoral Immune Response and Performance of Quail Chicks Fed Supplemental Chromium. Int. J. of Poult. Sci. 7 (1): 4044.

El-Sheikh, A.M.H.; E.A. Abdella and M.M. Hanafy (2010). The effect of organic selenium supplementation on productive and physiological performance in a local strain of chicken.2- immune system and some physiological aspects in bandarah chicks affected by organic selenium. Egypt. Poult. Sci. Vol (30) (II): (517-533).

Gabriel, J. E; L. E. Alvares; M. C. Gobet; C. C. P. De Paz; I. U. Packer; M. Macari; and L. L. Coutinho, (2003). Expression of myoD, myogenin, myostatin and hsp70 transcripts in chicken embryos submitted to mild cold or heat. J. Therm. Biol. 28:261-269.

Gallo-Torres D.C. (1980): Absorption, blood transport and metabolism of vitamin E. In: Maclin L.J. (ed.): A Comprehensive Treatise. Marcel Dekker, New York. 170 -267.

Gowdy, K.M. (2004). Selenium Supplementation and Antioxidant Protection in Broiler Chickens. M.Sc.Thesis, Univ. North Carolina State, Raleigh

Henry, R. J. (1974). Clinical Chemistry: Principles and Techniques. New York, NY: Harper and Row.

Hitchner, S.B., Domrmuth, C.H., Purchase, H.G. and Williams, J.E.. (1980). Isolation and identification of avian pathologists. Creative Printing Company Inc. Endwell. NY.

Houston, B.B. and Neill, IE.O. (1991). Insulin and insulin-like growth factor production by cultured chicken hepatocytes. J. Endocrinol., 128: 389-393.

Kapakin K.A.T; K. Halit; G. Recep; K. Samet and S.S. Yavuz (2013). Effect of Vit E on Secretion of HSP70 in Testes of Broilers Exposed to Heat Stress. Kafkas Univ Vet Fak Derg 19 (2): 305-310.

Lee, D.N.; F.Y. Wu; Y.H. Cheng; R.S. Lin and P.C. Wu (2003). Effect of dietary chromium picolinate supplementation on growth performance and immune responses of broilers. Asian Austr. J. Anim. Sci., 16: 227-233.

Leshchinsky T. V. and K. C. Klasing, (2001). Relationship between the Level of dietary vitamin E and the immune response of broiler chickens. Poult. Sci. 80:1590-1599. 


\section{Gouda et al.}

Lin, H.; E. Decuypere and J. Buyse. (2006). Acute heat stress induces oxidative stress in broiler chickens. Comp. Biochem. Physiol. Part A 144, 11-17.

Lin, H.; E. Decuypere and J. Buyse. (2006). Acute heat stress induces oxidative stress in broiler chickens. Comp. Biochem. Physiol. Part A 144, 11-17.

Mahmoud, K. Z. and F. W. Edens (2005). Influence of organic selenium on hsp70 response of heat-stressed and enteropathogenic Escherichia coli-challenged broiler chickens (Gallus gallus). Comp. Biochem. and Physi., Part C 141 69- 75.

Mahmoud, K. Z. and F. W. Edens (2003). Influence of selenium sources on age-related and mild heat stressrelated changes of blood and liver glutathione redox cycle in broiler chickens (Gallus dmesticus). Comp. Biochem. And Phys.- Biochem and Molec. Biol. 137:921-934.

McDowell L.R. (ed.) (1989). Vitamins in Animal Nutrition - Comparative Aspects to Human Nutrition. Vitamin A and E. Academic Press, London. 10-52, 93-131.

Metwally, M. A. (2003). Effect of varying levels of dietary vitamin A and E and selenium and their interactions on performance, blood constituents, bone ash and immune response of broiler chicks. 92nd Annual Meeting Abstracts, July 6-9, 2003. 325.

Moreno-Reyes, R.; D. Egrise; J. Nève; J.L. Pasteels and A. Schoutens (2001). Selenium deficiency-induced growth retardation is associated with an impaired bone metabolism and osteopenia. J. Bone Miner Res16 (8): $1556-63$.

Mujahid, A.; K. Sato; Y. Akiba and M. Toyomizu, (2006). Acute heat stress stimu- lates mitochondrial superoxide production in broiler skeletal muscle, possibly via downregulation of uncoupling protein content. Poult. Sci. 85, 1259-1265.

Mujahid, A.; N.R. Pumford; W. Bottje; K. Nakagawa; T. Miyazawa; Y. Akiba and M. Toyomizu (2007). Mitochondrial oxidative damage in chicken skeletal muscle induced by acute heat stress. J. Poult. Sci. 44, 439-445.

Mujahid, A.; Pumford, N. R.; Bottje, W.; Nakagawa, K.; Miyazawa, T.; Akiba, Y. and Toyomizu, M. (2008). Mitochondrial oxidative damage in chicken skeletal muscle induced by acute heat stress. J. Poult. Sci. 44, 439-445.

Niu, Z.Y.; F.Z. Liu; Q. L. Yan and W.C. Li (2009). Effects of different levels of vitamin E on growth performance and immune responses of broilers under heat stress. Poult. Sci., 88, 2101-2107.

Packer, L. and Y. Suzuki, (1993). Vitamin E and alpha-lipoate: Role in antioxidant recycling and activation of the NF- $\kappa$ B transcription factor. Mol. Asp. Med. 14:229-239.

Rashidi A.A.; Y. Gofranilvari; A. khatibjoo and R. Vakili (2010). Effects of dietary fat, vitamin E and zinc on immune response and blood parameters of broiler reared under heat stress. Res. J. of Poult. Sci. 3: 3238.

Sahin K.; O. Kucuk; N. Sahin and O. Ozbey (2001). Effects of dietary chromium picolinate supplementation on egg production, egg quality, and serum concentrations of insulin, corticostrerone and some metabolites of Japanese Quails. Nut. Res. 21(9):1315-1321.

Sahin, K.; N. Sahin and O. Kucuka (2003). Effects of chromium, and ascorbic acid supplementation on growth, carcass traits, serum metabolites, and antioxidant status of broiler chickens reared at a high ambient temperature. Nutr. Res., 23: 225-238.

Sahin, K.; N. Sahin; M. Onderci; F. Gursu and G. Cikim, (2002a). Optimal dietary concentration of chromium for alleviating the effect of heat stress on growth, carcass qualities and some serum metabolites of broiler chickens. Biol. Trace Elet. Res., 89: 53-64.

Sahin, K.; O. Kücük; N. Sahin, and M. Sari (2002b). Effects of vitamin C and vitamin E on lipid peroxidation status, serum hormone, metabolite, and mineral concentrations of Japanese. Quails reared under heat stress. (34 degrees C). Int J. Vit. Nutr.Res. 72: 91-100.

Samar S. T.; K. M. A. Hassanin. and I. M. I. Youssef (2014). The Effect of Dietary Supplementation of Some Antioxidants on Performance, Oxidative Stress, and Blood Parameters in Broilers under Natural Summer Conditions. J. World's Poult. Res. 4(1): 10-19 
Sands, J. S. and M. O. Smith (2002). Broilers in heat stress conditions: Effects of dietary Manganese proteinate or Chromium picolinate supplementation. J. Appl. Poultry. Res. 8: 280 -287.

SAS (1996). SAS/STAT®User's Guide: Statistics Ver. 6.04, 4th ed. SAS Institute Inc., Cary, NC

Smith, J.; J. Harner; D. Durham; J. Stevenson; J. Shirley; G. Stokka and M. Meyer (1998). Coping with summer weather; Dairy management strategies to control heat stress. Kansas State University. USA.

Swain, B. K.; T. S. Johri, and S. Majumdar (2000). Effect of supplementation of vitamin E, selenium and their different combinations on the performance and immune response of broilers. Br. Poult. Sci., 41: 287-292.

Uyanik, E.; A. Atasever; S. Ozdamar and F. Aydin (2000). Effect of dietary chromium chloride supplementation on performance, some serum parameters and immune response in broilers. Biological Trace Element Res., 90: 99-115. (Poult. Abstr., 2003, 29: 1452).

Weberi, M.; J. Fodor; K. Balogh; L. Wagner, M. Erdelyi, and M. Mezes. (2008). Effect of vitamin E supplementation on immunity against Newcastle Disease Virus in T-2 toxin challenged chickens. Acta Vet. Brno.77: 45-49.

Wolf, G. 2005. The discovery of the antioxidant functions of vitamin E: the contribution of Henry A. Mattill. J. Nutr. 135:363-366.

World Meteorological Organization (W.M.O). (1996). Guide to meteorological instruments and methods of observation. Sixth edition. Geneva, Switzerland.

Yang, N.; C. T. Larsen; E. A. Dunnington; P. A. Geraert; M. Picard, and P. B. Siegel (2000). Immune competence of chicks from two lines divergently selected for antibody response to sheep red blood cells as affected by supplemental vitamin E. Poult. Sci., 79:799-803.

Zou, J.; W.F. Salminen; S.M. Roberts and R. Voellmy (1998). Correlation between glutathione oxidation and trimerization of heat shock factor 1, an early step in stress induction of the hsp response. Cell Stress Chaperon 3 (2), 130-141.

\section{الاستجابه الفسيولوجيه لاجاج التسمين تحت ظروف الاجهاد الحراري لبعض اضافات مضدات الاكسده العضويه}

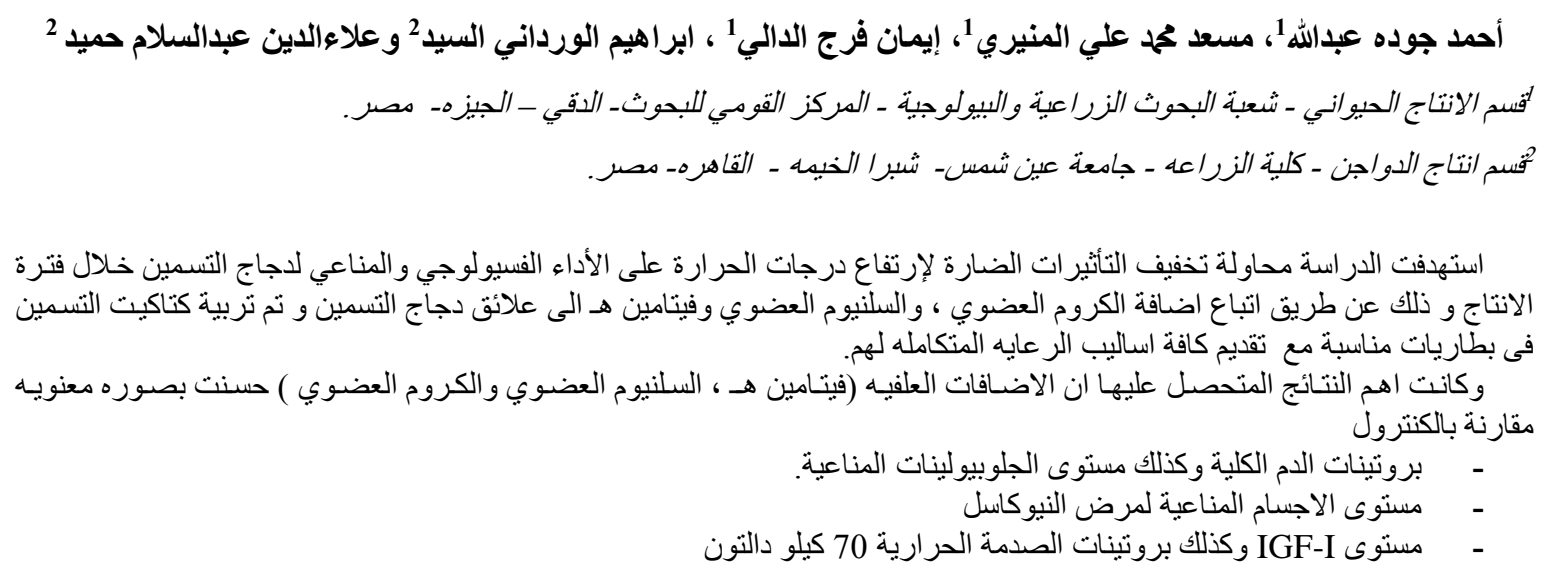

